\title{
Preconditioning and Acute Effects of Flavonoids in Protecting Cardiomyocytes from Oxidative Cell Death
}

\author{
Masoumeh Akhlaghi', ${ }^{1,2}$ and Brian Bandy ${ }^{2}$ \\ ${ }^{1}$ College of Health and Nutrition, Shiraz University of Medical Sciences, P.O. Box 71645-111, Shiraz, Iran \\ ${ }^{2}$ College of Pharmacy and Nutrition, University of Saskatchewan, Saskatoon, SK, Canada S7N 5C9
}

Correspondence should be addressed to Brian Bandy, b.bandy@usask.ca

Received 5 February 2012; Revised 14 May 2012; Accepted 21 May 2012

Academic Editor: Cristina Angeloni

Copyright (C) 2012 M. Akhlaghi and B. Bandy. This is an open access article distributed under the Creative Commons Attribution License, which permits unrestricted use, distribution, and reproduction in any medium, provided the original work is properly cited.

\begin{abstract}
While flavonoids can reportedly protect against cardiac ischemia-reperfusion injury, the relative effectiveness of different flavonoids and the mechanisms involved are unclear. We compared protection by different flavonoids using rat embryonic ventricular H9c2 cells subjected to simulated ischemia-reperfusion (IR) and to tert-butyl hydroperoxide ( $t$-buOOH). Characterization of the IR model showed the relative contributions of glucose, serum, and oxygen deprivation to cell death. With long-term (2-3 day) pretreatment before IR the best protection was given by catechin, epigallocatechin gallate, proanthocyanidins, and ascorbate, which protected at all doses. Quercetin protected (34\%) at $5 \mu \mathrm{M}$ but was cytotoxic at higher doses. Cyanidin protected mildly (10$15 \%$ ) at 5 and $20 \mu \mathrm{M}$, while delphinidin had no effect at $5 \mu \mathrm{M}$ and was cytotoxic at higher doses. Comparing long-term and acute protection by catechin, a higher concentration was needed for benefit with acute $(1 \mathrm{hr})$ pretreatment. With a pure oxidative stress $(t$-buOOH $)$ only quercetin significantly protected with 3 -day pretreatment, while with short-term $(1 \mathrm{~h})$ pretreatments protection was best with quercetin and epigallocatechin gallate. The results suggest catechins to be especially useful as IR preconditioning agents, while quercetin and epigallocatechin gallate may be the most protective acutely in situations of oxidative stress.
\end{abstract}

\section{Introduction}

Ischemia and reperfusion in the myocardium initiates metabolic and ionic perturbations, mostly as a result of oxidative stress, ultimately leading to cell demise and tissue necrosis. Although recent notions have posed myocardial cell renewal as a part of normal cardiac homeostasis [1], cardiac cells likely have limited ability to proliferate. Hence, reducing cell death during ischemia-reperfusion is of great importance in preventing the irreversible injury.

Polyphenols and especially flavonoids are well acknowledged for their antioxidant and protective effects in circumstances of oxidative stress $[2,3]$. They have also been recognized to interact with cell death-survival signaling pathways which depending on the dose may promote or inhibit apoptosis, exhibiting chemopreventive or cytoprotective effects, respectively $[4,5]$.

A large body of evidence points to protective effects of flavonoids against cardiac ischemia-reperfusion injury (e.g., reviewed in Akhlaghi and Bandy [6]). However, in most studies the cardioprotective effect of a single flavonoid has been investigated. Only one in vitro report has compared effects of a few flavonoids from two classes on ischemiareperfusion-induced cell death [7].

One goal of the current study therefore, using cultured rat embryonic ventricular $\mathrm{H} 9 \mathrm{c} 2$ cells, was to compare a broader variety of flavonoids. In this study, we compared flavonoids from flavonol (catechin and proanthocyanidins), catechin gallate (epigallocatechin gallate), flavonol (quercetin), and anthocyanin (cyanidin, delphinidin) classes (Figure 1). Such a comparison could help distinguish which types of flavonoids might be most effective in protecting against ischemia-reperfusion injury. Ascorbate was also compared as another factor in fruit and vegetables that may help protect [8].

A second goal was to distinguish indirect (preconditioning) effects versus direct effects. Because flavonoids may produce protection indirectly, for instance, through inducing 
phase 2 enzymes and endogenous antioxidant systems [9], we compared short-term ( $1 \mathrm{hr}$ ) with long-term (2-3 day) exposure prior to the oxidative stress. The short-term pretreatment was designed to allow enough time for the flavonoids to be taken up into the cells and provide direct antioxidant or other effects during ischemia and reperfusion, but not enough time for preconditioning requiring protein induction and synthesis. The long-term pretreatment would additionally allow such preconditioning. Also, to evaluate different oxidative stimuli which may provoke different signaling cascades [10], we compared simulated ischemiareperfusion with exposure of the cells to tert-butyl hydroperoxide $(t$-buOOH).

\section{Materials and Methods}

2.1. Materials. Quercetin, (+)-catechin, epigallocatechin gallate, gallic acid, caffeic acid, resveratrol and sodium ascorbate were purchased from Sigma. Delphinidin and cyanidin were from Extrasynthèse SA (Genay Cedex, France). Activin Grape Seed Extract (95\% proanthocyanidins) was from Trophic Canada Ltd.

2.2. Cell Culture. Rat embryonic ventricular cells, H9c2 (American Tissue Culture Collection, Manassas, VA), were cultured in Dulbecco's modified Eagle's medium (DMEM) containing $1.5 \mathrm{~g} / \mathrm{L} \mathrm{NaHCO}_{3}$ and $1.0 \mathrm{~g} / \mathrm{L}$ glucose, supplemented with $10 \%$ fetal bovine serum (FBS), $100 \mathrm{U} / \mathrm{mL}$ penicillin, and $100 \mathrm{U} / \mathrm{mL}$ streptomycin. Tissue culture flasks were kept at $37^{\circ} \mathrm{C}$ in a humidified atmosphere of $5 \% \mathrm{CO}_{2}$. The medium was changed every 2-3 days and the cells were subcultured regularly. For experiments, cells were cultured on 96-well plates, kept in DMEM with 10\% FBS until confluency, and then were switched to DMEM with 2\% FBS.

2.3. Treatment with Flavonoids. Confluent cells were treated with various concentrations of flavonoids (in dimethyl sulfoxide) for different time courses prior to induction of ischemia or incubation with t-buOOH. The concentrations were those that could be achieved in plasma with acute or long-term dietary supplementation $(5-10 \mu \mathrm{M}$ at high levels) [11-13] and supraphysiologic concentrations that could be administered intravenously or added to cardioplegic solutions in situations such as coronary bypass surgery or heart transplant. The concentration of dimethyl sulfoxide in DMEM was kept equal to or less than $0.05 \% \mathrm{v} / \mathrm{v}$. The concentrations of ascorbate used were those normally in plasma $(\sim 100 \mu \mathrm{M})$ and those that can be achieved with supplementation (up to $250 \mu \mathrm{M}$ ) or intravenous administration [14].

2.4. Ischemia-Reperfusion. To induce ischemia, after removing DMEM, cells were washed twice with phosphate-buffered saline (PBS) (140 mM NaCl, $2.7 \mathrm{mM} \mathrm{KCl}, 8.1 \mathrm{mM} \mathrm{Na}_{2} \mathrm{HPO}_{4}$, and $\left.1.5 \mathrm{mM} \mathrm{KH}_{2} \mathrm{PO}_{4}, \mathrm{pH} 7.3\right)$ and covered with $100 \mu \mathrm{L}$ of ischemia-mimetic solution containing $140 \mathrm{mM} \mathrm{NaCl}$, $1.25 \mathrm{mM} \mathrm{CaCl}_{2}, 1 \mathrm{mM} \mathrm{MgCl} 2,8 \mathrm{mM} \mathrm{KCl}$, and $6 \mathrm{mM}$ HEPES, pH 6 [15]. The ischemia solution was bubbled with 100\% nitrogen gas for at least $30 \mathrm{~min}$ before adding to the cells. The cells were placed in a $37^{\circ} \mathrm{C}$ modular hypoxia chamber, and the chamber was flushed with nitrogen gas for the initial $1.5 \mathrm{~h}$ of ischemia and sealed for the rest of the ischemic period. The time course of flushing $(1.5 \mathrm{~h})$ was chosen according to the initial experiments when the atmosphere of the chamber was tested with the oxygen indicator methylene blue. The ischemia was established for $5 \mathrm{~h}$ followed by reperfusion for $18 \mathrm{~h}$. For reperfusion, the ischemia solution was replaced with DMEM (with 2\% FBS) containing $300 \mathrm{mg} / \mathrm{L} \mathrm{NaHCO}_{3}$ and flavonoids (if any), and the plates were placed in the same chamber as the control plates. In preliminary experiments, we determined that $300 \mathrm{mg} / \mathrm{L} \mathrm{NaHCO}$ was sufficient to keep the $\mathrm{pH}$ at 7.4 during the $18 \mathrm{hr}$ reperfusion in room air (with $<0.1 \% \mathrm{CO}_{2}$ ).

Cells in control (nonischemic) groups experienced the same procedures including washing steps, and the DMEM was replaced with fresh DMEM containing $300 \mathrm{mg} / \mathrm{L}$ $\mathrm{NaHCO}_{3}$. Control plates were kept at $37^{\circ} \mathrm{C}$ in a humidified chamber containing ambient air throughout the experiment. Those wells in the control plate which had been treated with flavonoids were treated the same during the experiment.

2.5. Treatment with Tert-Butyl Hydroperoxide. In hydroperoxide experiments, after treatment with flavonoids or ascorbate, cells were incubated with $400 \mu \mathrm{M} t$-buOOH for $24 \mathrm{~h}$ before cell viability assessment.

2.6. MTT (3-(4,5-Dimethyl-2-Thiazolyl)-2,5-Diphenyltetrazolium Bromide) Assay. The method used was a modification of the method used by Denizot and Lang [16]. After reperfusion, the medium was removed and the cells were washed twice with PBS to remove residual flavonoids. Then, $100 \mu \mathrm{L}$ of solution containing $140 \mathrm{mM} \mathrm{NaCl}, 1.25 \mathrm{mM} \mathrm{CaCl}_{2}, 1 \mathrm{mM}$ $\mathrm{MgCl}_{2}, 6 \mathrm{mM} \mathrm{KCl}, 10 \mathrm{mM}$ glucose, and $6 \mathrm{mM}$ HEPES, $\mathrm{pH}$ 7.4 was added to each well, and the cells were incubated at $37^{\circ} \mathrm{C}$ with final concentration of $0.5 \mathrm{mg} / \mathrm{mL}$ MTT (in PBS). After $1 \mathrm{~h}$, the solution was removed and purple formazan crystals were solubilized in $100 \mu \mathrm{L}$ dimethyl sulfoxide for $15 \mathrm{~min}$, and the absorbance was determined at $570 \mathrm{~nm}$ using an absorbance spectrophotometer.

2.7. Microscopic Determination of Cell Viability. To facilitate counting, the cells were incubated with a final concentration of $4 \mu \mathrm{g} / \mathrm{mL}$ acridine orange (in PBS) added to the medium [17]. After $1 \mathrm{~h}$, the medium was aspirated, the cells were washed with PBS, $100 \mu \mathrm{L}$ of the above-mentioned solution containing $140 \mathrm{mM} \mathrm{NaCl}, 1.25 \mathrm{mM} \mathrm{CaCl}, 1 \mathrm{mM} \mathrm{MgCl}$, $6 \mathrm{mM} \mathrm{KCl}, 10 \mathrm{mM}$ glucose, and $6 \mathrm{mM}$ HEPES (pH 7.4) was added to each well to maintain the cells alive, and the cells were visualized using a fluorescence microscope. As dead cells were washed away during the washing process, the only cells observed on the microscope were live cells. A specific area from each well with a magnification of $10 \mathrm{x}$ was chosen for imaging.

2.8. Glyceraldehyde-3-Phosphate Dehydrogenase (GAPDH). The activity of GAPDH was used as an indicator of cell death. The activity of GAPDH released into the medium was measured using aCella-TOX kit according to the manufacturer's instructions. 
<smiles>Oc1cc(O)c2c(c1)O[C@H](c1ccc(O)c(O)c1)[C@H](O)C2</smiles>

$(+)$-catechin<smiles>O=C(O[C@H]1Cc2c(O)cc(O)cc2O[C@@H]1c1cc(O)c(O)c(O)c1)c1cc(O)c(O)c(O)c1</smiles>

(-)-epigallocatechin gallate<smiles></smiles>

Cyanidin<smiles>Oc1cc(O)c2c(c1)O[C@H](c1ccc(O)c(O)c1)[C@H](O)[C@H]2c1c(O)cc(O)c2c1O[C@H](c1ccc(O)c(O)c1)[C@H](O)[C@H]2c1c(O)cc(O)c2c1O[C@H](c1ccc(O)c(O)c1)[C@H](O)C2</smiles>

Procyanidin trimer<smiles>Oc1cc(O)c2cc(O)c(-c3cc(O)c(O)c(O)c3)[o+]c2c1</smiles>

Delphinidin<smiles>O=c1c(O)c(-c2ccc(O)c(O)c2)oc2cc(O)cc(O)c12</smiles>

Quercetin

Figure 1: Flavonoids studied. The flavonoids studied were flavonols (catechin and a proanthocyanidin mixture including procyanidin trimer), a catechin gallate (epigallocatechin gallate), a flavonol (quercetin), and anthocyanins (cyanidin and delphinidin).

2.9. Statistics. Data represent means \pm SEM. Statistical analyses were performed with SPSS software using one-way analysis of variance (ANOVA). As a post hoc test, 2-sided Dunnett was used to compare treatments with either nonischemic control (named as control in graphs) or ischemicreperfused control (named as IR in graphs). In nonischemia conditions, flavonoid treatments were compared with the nonischemia control, while in ischemia-reperfusion conditions, flavonoid-treated groups were compared with the IR control. A $P$ value of less than 0.05 was considered significant.

\section{Results}

3.1. Ischemia-Reperfusion Experiments. Cell death in this model occurred as a result of hypoxia, serum removal, and glucose deprivation (Figure 2). Each of these factors contributed to cell death, with lack of oxygen contributing 34\% $(100 \times(\mathrm{MR} / \mathrm{R}-\mathrm{I} / \mathrm{R}) /($ Control-I/R $))$, lack of glucose contributing $24 \%(100 \times(\mathrm{HSR} / \mathrm{R}-\mathrm{I} / \mathrm{R}) /(\mathrm{Control}-\mathrm{I} / \mathrm{R}))$, and the lack of FBS contributing $42 \%$ (the remaining proportion of cell death).

Three-day pretreatment with different concentrations of flavonoids showed little or no protection by quercetin, cyanidin, or delphinidin (Figure 3 ) and notable protection by catechin (Figure 3). Concentrations of 5 to $50 \mu \mathrm{M}$ catechin improved cell viability by 21 to 58 percent, while cyanidin gave significant mild protection (10-15\%) at 5 and $20 \mu \mathrm{M}$.

Because catechin gave the strongest protection, we conducted additional experiments comparing different catechins (epigallocatechin gallate and a proanthocyanidin mixture) (Figure 4). Like catechin, concentrations of 5 to $100 \mu \mathrm{M}$ 


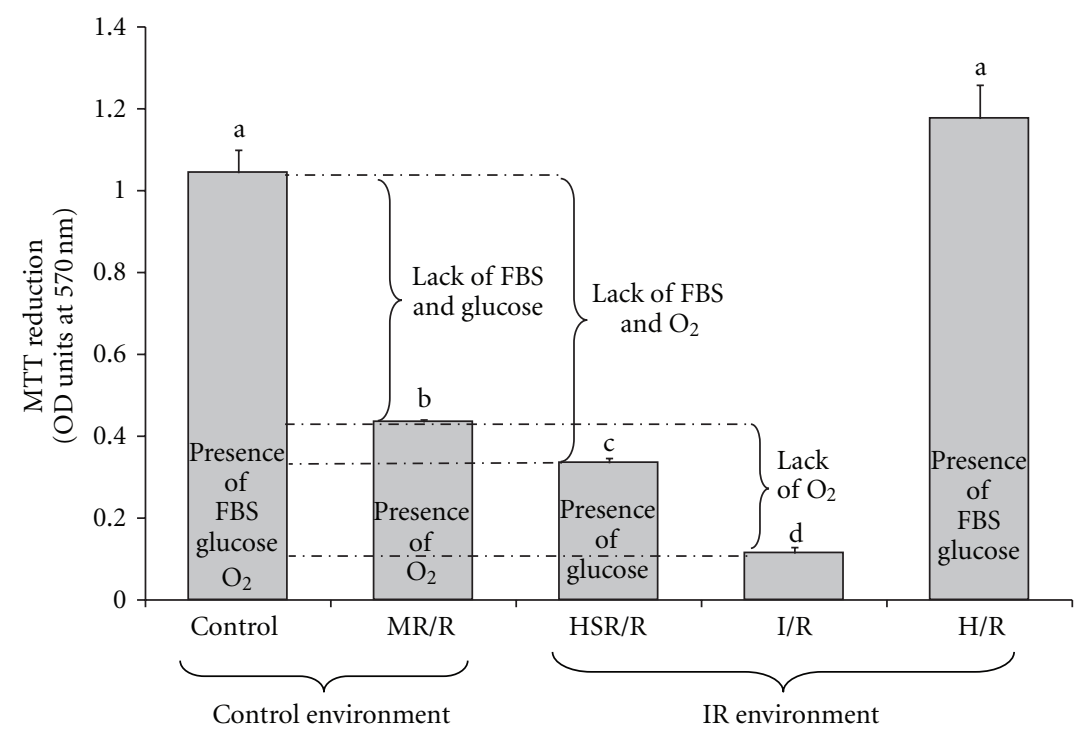

FIGURE 2: Contributions of oxygen, glucose, and serum removal on ischemia-reperfusion-induced cell death in H9c2 cells. Cell viability was assessed by the MTT assay as described in Section 2. The condition of the experiment for different groups was as follows: Control, cells were kept in the control environment (presence of oxygen) and received DMEM plus FBS throughout the experiment. MR/R (medium restriction/reperfusion), cells were placed in the control environment (presence of oxygen) and received ischemia solution during the time of ischemia and DMEM plus FBS during the time of reperfusion. HSR/R (hypoxia-serum restriction/reperfusion), cells were placed in the ischemia environment (absence of oxygen) and received ischemia solution plus glucose $\left(\mathrm{N}_{2}\right.$-saturated) during hypoxia and transferred to the control environment (presence of oxygen) and treated with DMEM plus FBS during reperfusion. I/R (ischemia/reperfusion), cells were placed in the ischemia environment (absence of oxygen) and received ischemia solution during ischemia and transferred to the control plate (presence of oxygen) where they received DMEM plus FBS during reperfusion. H/R (hypoxia/reperfusion), cells were kept in the ischemia environment (absence of oxygen) during ischemia and transferred to the control plate (presence of oxygen) during reperfusion but received DMEM plus FBS throughout the experiment. Bars represent means of 3-6 wells \pm SEM. ${ }^{\mathrm{a}-\mathrm{d}}$ Letters that are different indicate a significant difference at $P<0.05$.

epigallocatechin gallate and proanthocyanidins also gave 28 to 49 and 22 to 44 percent protection, respectively, which in some concentrations was statistically significant (Figure 4).

To see if the length of pretreatment is effective in the protection observed, catechin was tested in short- $(1 \mathrm{~h})$ and long-(2-3 days) term pretreatments. Whereas in long-term (2-3 days) applications concentrations of catechin as low as 5 to $10 \mu \mathrm{M}$ exhibited almost $50 \%$ protection (Figures 4 and 5), in short-term $(1 \mathrm{~h})$ pretreatment $50 \mu \mathrm{M}$ catechin gave a $98 \%$ improvement in cell viability, while $10 \mu \mathrm{M}$ catechin showed nonsignificant protection (Figure 5).

Sodium ascorbate also gave significant protection (57$92 \%$ ) at all concentrations tested (Figure 6).

3.2. Hydroperoxide Experiments. To investigate any differences between protection against ischemia-reperfusion and a pure oxidative stress, experiments were conducted with $t$-buOOH. The cells were pretreated for 3 days with a concentration of $25 \mu \mathrm{M}$ of flavonoids. Except quercetin which exhibited $46 \%$ protection against cell death caused by $t$-buOOH, none of the other compounds protected cells at this concentration and time course of treatment (Figure 7). Conversely, some compounds, that is, cyanidin, delphinidin, epigallocatechin gallate, and proanthocyanidins worsened cytotoxicity in the presence of $t$-buOOH after 3 -day pretreatment. Short-term $(1 \mathrm{~h})$ pretreatment however did not produce cytotoxicity even when a higher concentration of flavonoids was used (Figure 7). With short-term incubation, epigallocatechin gallate gave cytoprotection $(66 \%)$ rather than cytotoxicity, and it along with quercetin was the only compound that inhibited $t$-buOOH-induced cell death, increasing cell survival by 66 and 95 percent (Figure 7).

The protective effect of epigallocatechin gallate and quercetin on $\mathrm{H} 9 \mathrm{c} 2$ cells against $t$-buOOH was confirmed when the medium was tested for released glyceraldehyde-3phosphate dehydrogenase (Figure 8).

As short-term exposure to catechin protected at a higher concentration in the ischemia-reperfusion model (Figure 5) but did not protect at $25 \mu \mathrm{M}$ in the $t$-buOOH experiments (Figure 7), an experiment was performed using different concentrations of catechin along with a comparison between catechin and epigallocatechin gallate. Catechin did show significant protection against $t$-buOOH but only at $100 \mu \mathrm{M}$ (Figure 9). Epigallocatechin gallate showed stronger protection and protected significantly at $50 \mu \mathrm{M}$ and $100 \mu \mathrm{M}$ (Figure 9).

\section{Discussion}

The main objective of the ischemia-reperfusion study was to compare the protective effects of flavonoids against cell death caused by ischemia-reperfusion. An in vitro model of ischemia-reperfusion [15] was used to mimic the in vivo situation. An evaluation of the components of this model 


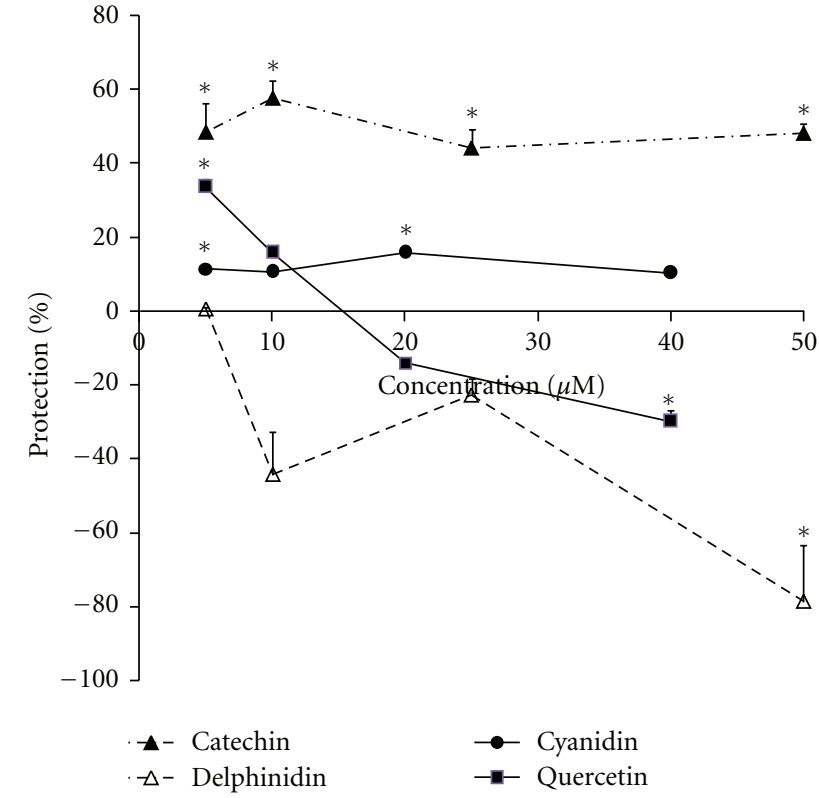

FIgURE 3: Protection compared to IR control in H9c2 cells pre-treated for 3 days with catechin, quercetin, cyanidin, and delphinidin before exposure to ischemia-reperfusion. Confluent cells were kept in 2\% FBS-DMEM for 6 days including 3-day pretreatment with different concentrations of the flavonoids, and then ischemia and reperfusion were established according to the procedure described in Section 2. The flavonoids were also present during the reperfusion time. For the experiments with catechin and delphinidin, the number of live cells was counted after staining cells with acridine orange. For the experiments with quercetin and cyanidin, viability was measured by the MTT method. Data are expressed as the percent protection compared to the nonischemic and IR controls. Points are means of $4-5$ wells \pm SEM. ${ }^{*}$ Represents $P<0.05$ versus the control ischemic-reperfused condition. In the control condition (4 days total treatment without ischemia) 40 $50 \mu \mathrm{M}$ quercetin or delphinidin showed significant cytotoxicity (inhibiting cell growth by 25-55\%), while lower concentrations did not (results not shown).

(Figure 2) showed that death of H9c2 cells occurred as a consequence of serum removal, hypoxia, and glucose deprivation. The process of cell death caused by serum removal reportedly involves mitochondrial dysfunction [18] that leads to increased production of reactive oxygen species $[18,19]$. Thus, up to $76 \%$ of the death which occurred after FBS and oxygen deprivation may have been related in some way to oxidative stress, with the remaining $24 \%$ from glucose (energy) deprivation. In addition, serum removal causes release of $\mathrm{Ca}^{2+}$ from endoplasmic reticulum [20], resulting in cellular $\mathrm{Ca}^{2+}$ overload, one of the prominent consequences of ischemia-reperfusion [21]. Thus, the serum withdrawalinduced changes in reactive oxygen species and cellular $\mathrm{Ca}^{2+}$ resemble those that happen in in vivo conditions of ischemiareperfusion. Interestingly, hypoxia reoxygenation alone (without serum and glucose deprivation) did not decrease cell number (last bar in Figure 2). However, this does not necessarily mean that no cell death occurred in this group,

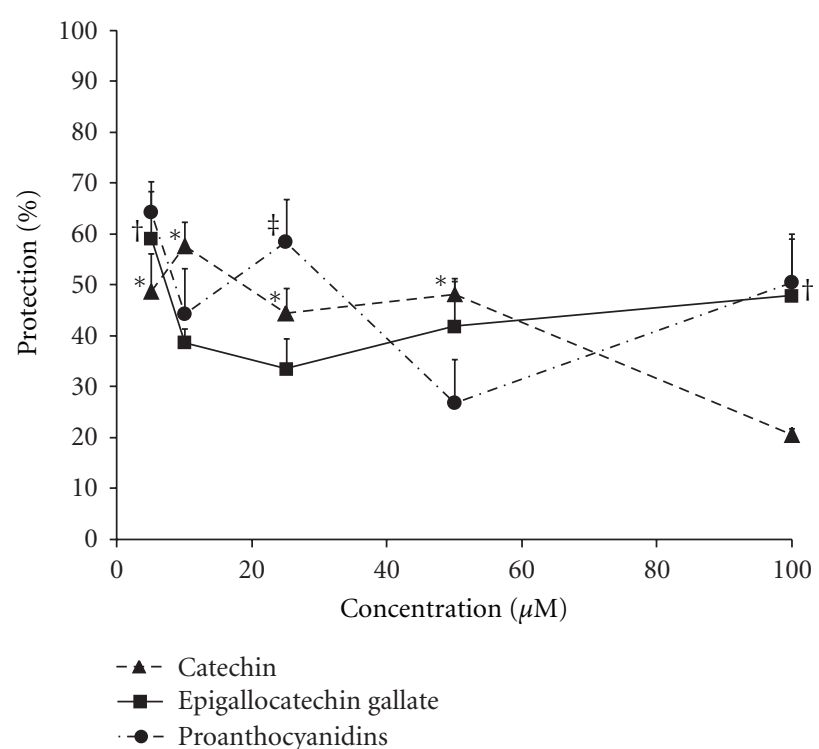

Figure 4: Protection by 3-day pretreatment with catechin, epigallocatechin gallate, or proanthocyanidins of $\mathrm{H} 9 \mathrm{c} 2$ cells exposed to ischemia-reperfusion. Confluent cells were kept in 2\% FBS-DMEM for 6 days including 3-day pretreatment with various concentrations of catechin (results from Figure 3 but with an additional point at $100 \mu \mathrm{M}$ ), epigallocatechin gallate, or proanthocyanidins, and then ischemia-reperfusion groups were exposed to $5 \mathrm{~h}$ ischemia followed by $18 \mathrm{~h}$ reperfusion. Catechin, epigallocatechin gallate, or proanthocyanidins were present during the reperfusion time. The number of live cells was counted after staining cells with acridine orange. Data were expressed as percent protection against cell death in treatment groups compared to the control nonischemic and ischemia-reperfusion conditions. Each point represents means of 3-4 wells \pm SEM. ${ }^{*},{ }^{\dagger}$, and ${ }^{\ddagger}$ Show $P<0.05$ versus nontreated ischemic-reperfused condition for catechin, epigallocatechin gallate, and proanthocyanidins, respectively. There were no significant effects of the flavonoids on growth and viability of the cells under the control (non-IR) condition (data not shown).

as both apoptosis and cell proliferation have been reported to be stimulated by hypoxia reoxygenation [22].

Among the tested flavonoids, those with a catechintype structure (catechin, epigallocatechin gallate, and proanthocyanidins) inhibited cell death induced by simulated ischemia-reperfusion. Notably, the catechins were present for 3 days prior to ischemia-reperfusion, allowing adaptations such as induction of phase 2 and antioxidant enzymes as previously observed $[23,24]$, as well as during ischemia and reperfusion, allowing direct antioxidant effects. These results support previous findings of protection by catechins in models of ischemia-reperfusion in vitro and in vivo [2529]. It has also been reported that epigallocatechin gallate can inhibit apoptosis induced by serum removal in cultured neurons [30], suggesting that this flavonoid is capable of inhibiting at least this component of ischemia-reperfusion injury in cultured cells.

Interestingly, in long-term exposure prior to ischemiareperfusion dose response measurements did not show concentration as a factor (at least above $5 \mu \mathrm{M}$ ) in protection 


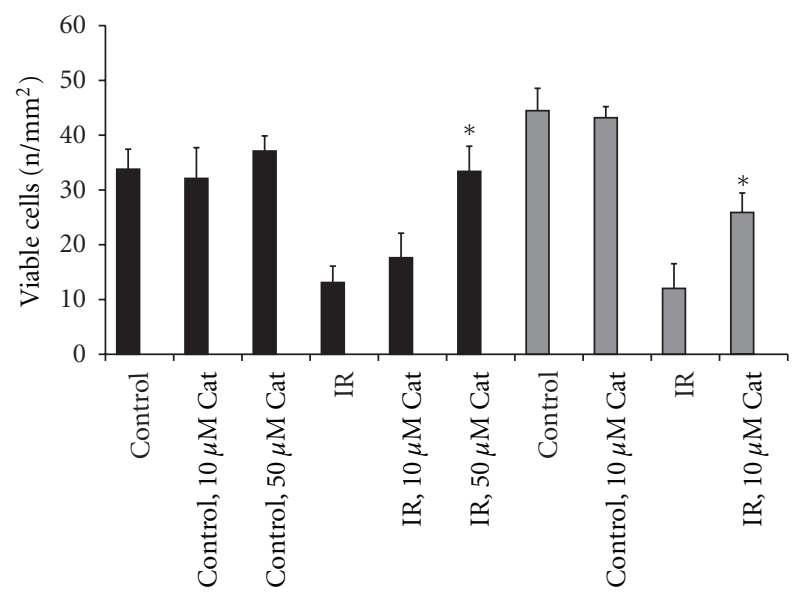

- Short-term treatment

口 Long-term treatment

FIgURE 5: Effects of short-( $1 \mathrm{~h})$ and long-(2 days) term pretreatment with catechin (Cat) in H9c2 cells subjected to ischemiareperfusion. Cells were kept in DMEM with 2\% FBS for 2 days and treated with either 10 or $50 \mu \mathrm{M}$ catechin for either $1 \mathrm{~h}$ (short-term) or 2 days (long-term) before induction of ischemia and reperfusion. Catechin was also present during the reperfusion. Live cells were counted with a microscope after staining cells with acridine orange. Columns are means of 8 wells \pm SEM. * Shows $P<0.05$ compared to the corresponding ischemia-reperfusion group (IR).

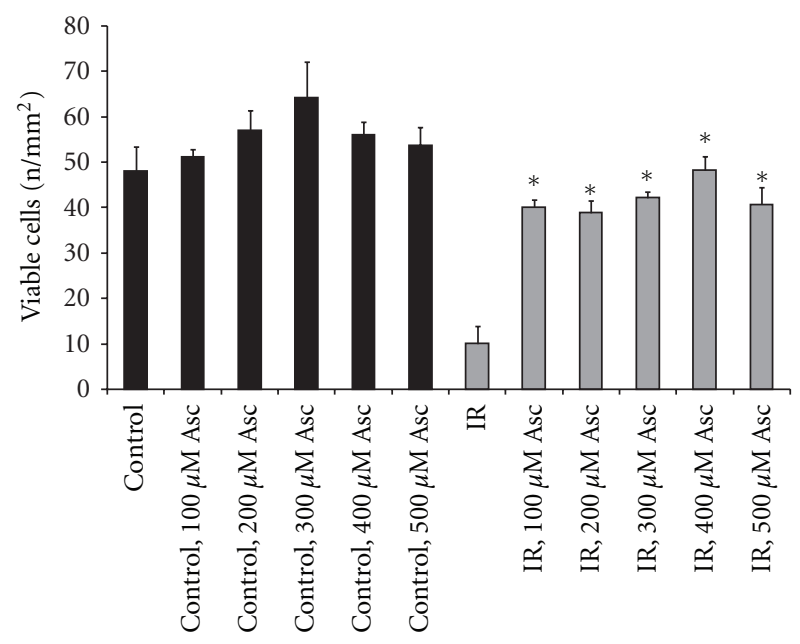

FIGURE 6: Effects of 3-day pretreatment with sodium ascorbate (Asc) against ischemia-reperfusion-induced cell death in H9c2 cells. Confluent cells were maintained in DMEM with 2\% FBS for 6 days including 3-day pretreatment with different concentrations of ascorbate, and then ischemia-reperfusion groups were exposed to ischemia and reperfusion. Ascorbate was also present during the reperfusion time. Cell viability was determined using a microscope after staining the cells with acridine orange. Bars are means of 45 wells \pm SEM. ${ }^{*}$ Indicates $P<0.05$ compared to the nontreated ischemic-reperfused group (IR). There were no significant effects of ascorbate on growth and viability of the cells under the control (non-IR) condition.

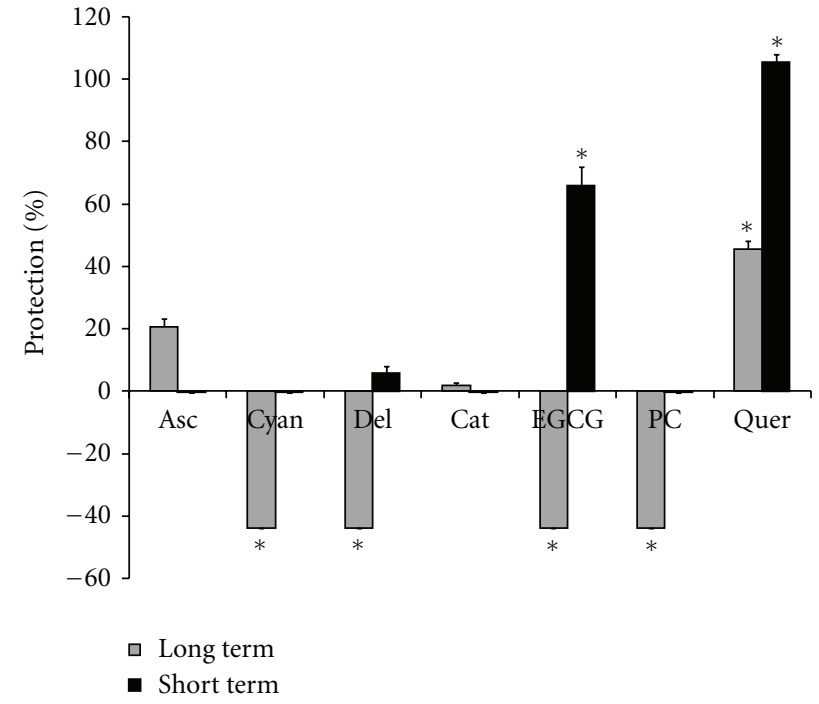

FIGURE 7: Protection by short- and long-term pretreatment with flavonoids against cell death caused by $t$-buOOH in $\mathrm{H} 9 \mathrm{c} 2$ cells. Long-term pretreatment: cells were kept in DMEM with 2\% FBS for 3-day treatment with $25 \mu \mathrm{M}$ of different flavonoids or $100 \mu \mathrm{M}$ sodium ascorbate prior to incubating with $400 \mu \mathrm{M} t$-buOOH for $24 \mathrm{hr}$. Live cells were then counted after staining with acridine orange. Short-term pretreatment: cells were kept in DMEM with $2 \%$ FBS for 3 days, and treated with $50 \mu \mathrm{M}$ of different flavonoids or $100 \mu \mathrm{M}$ sodium ascorbate for $1 \mathrm{~h}$. After the treatment periods, cells were incubated with $400 \mu \mathrm{M} t$-buOOH for $24 \mathrm{~h}$, and live cells were counted after staining with acridine orange. Bars show the percent protection upon treatment with flavonoids or ascorbate after incubation with $t$-buOOH. Asc: ascorbate; Cyan: cyanidin; Del: delphinidin; Cat: catechin; EGCG: epigallocatechin gallate; PC: proanthocyanidins; Quer: quercetin. * Indicates $P<0.05$ versus non-treated $t$-buOOH group.

exhibited by the catechins (Figure 4). In contrast, $50 \mu \mathrm{M}$ but not $10 \mu \mathrm{M}$ catechin was able to protect the cells with short-term pretreatment (Figure 5), suggesting that higher levels are required for direct antioxidant effects. It seems likely that direct antioxidant effects are dose dependent in this range because the antioxidant is competing with cellular components for the reactive species. With adaptive protection due to long-term exposure the response may be amplified through induction of antioxidant enzymes and thus occurred with lower levels of flavonoid. That the protection was already maximal at $5 \mu \mathrm{M}$ with long-term preexposure suggests that indirect adaptive responses have predominated in this condition.

Quercetin and one of the two examined anthocyanins (cyanidin) showed protection at a relatively low dose $(5 \mu \mathrm{M})$ against ischemia-reperfusion with long-term pre-exposure, but at higher concentrations quercetin (and delphinidin) exhibited cytotoxicity in control (data not shown) and IR conditions. Quercetin [31,32] and anthocyanins [3335] have previously been reported to provide protection in models of ischemia-reperfusion. However in the current study they were not as effective as catechins, and with quercetin and delphinidin in particular they showed 


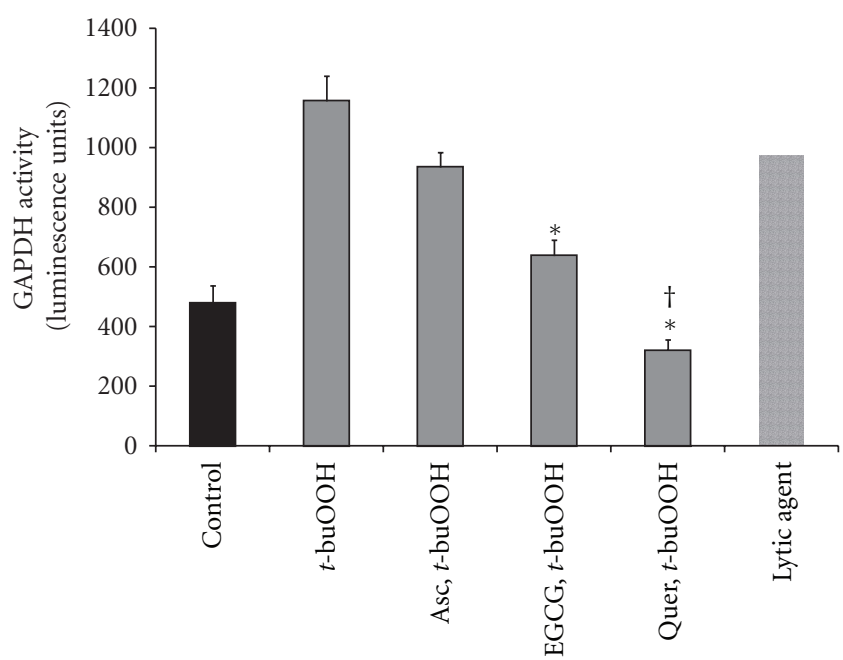

FIGURE 8: Effects of epigallocatechin gallate (EGCG), quercetin (Quer), or ascorbate (Asc) on glyceraldehyde-3-phosphate dehydrogenase (GAPDH) released to medium. Cells were treated with $50 \mu \mathrm{M}$ EGCG or Quer or $100 \mu \mathrm{M}$ sodium ascorbate for $1 \mathrm{~h}$ prior to $t$-buOOH. Cell death was tested by measuring GAPDH activity in the medium $24 \mathrm{~h}$ after treating cells with $400 \mu \mathrm{M} t$-buOOH. Bars are means of 3-4 wells \pm SEM. ${ }^{*}$ Shows $P<0.05$ versus $t$-buOOH. ${ }^{\dagger}$ Shows $P<0.05$ versus EGCG.

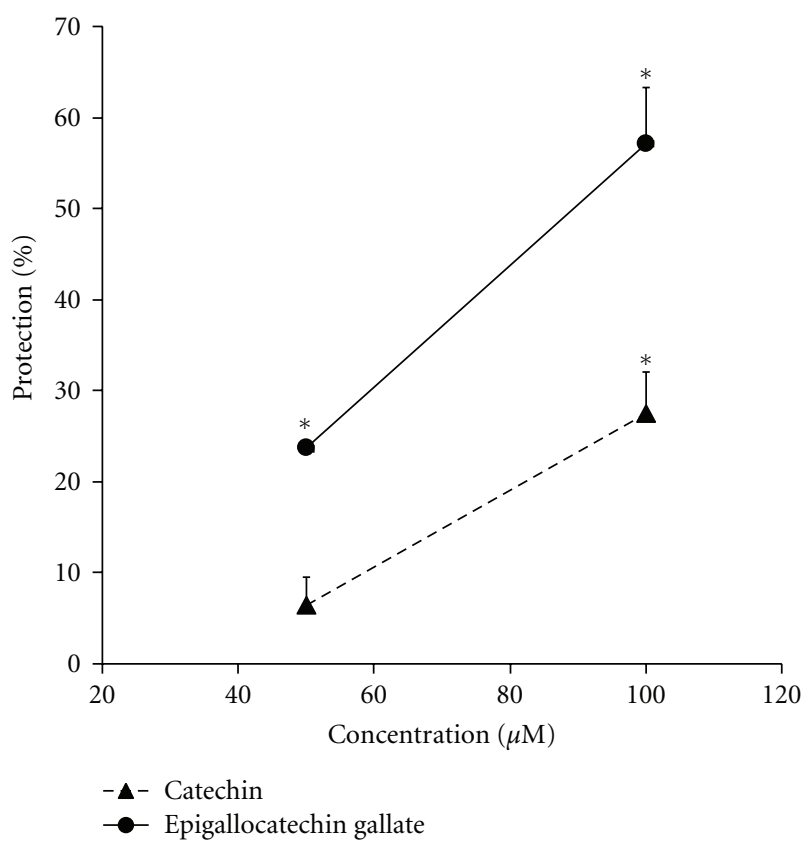

FIGURE 9: Protection by pretreatment with two concentrations of catechin and epigallocatechin gallate $1 \mathrm{~h}$ prior to incubation with $t$-buOOH. Cells were treated with 50 or $100 \mu \mathrm{M}$ catechin or epigallocatechin gallate for $1 \mathrm{~h}$. Then, cells were treated with $400 \mu \mathrm{M}$ $t$-buOOH for $24 \mathrm{~h}$ before counting live cells. Data were expressed as the percent protection. ${ }^{*}$ Shows $P<0.05$ versus non-treated $t$ buOOH group. a potential for cytotoxicity in the absence of ischemiareperfusion.

Ascorbate also showed strong protection against ischemia-reperfusion in this model with long-term exposure. Part of this protection may have been through pre-conditioning, as ascorbate oxidizes in cell culture media to produce $\mathrm{H}_{2} \mathrm{O}_{2}$ [36] and thereby may induce antioxidant enzymes in cultured cells. This result with ascorbate in the current model is consistent with previous findings of protection by ascorbate against other types of ischemia-reperfusion in vitro [37] and in vivo [38, 39].

In this ischemia-reperfusion model we tested whether catechin showed protection in short-term as well as longterm pretreatment. A low concentration (i.e., $10 \mu \mathrm{M}$ ) of catechin protected if left with the cells for prolonged preincubation times (in the day range), while a higher concentration (i.e., $50 \mu \mathrm{M}$ ) was needed to protect with shortterm $(1 \mathrm{~h})$ pretreatment. The reason for protection in the short-term pretreatment could be a direct antioxidant effect of catechin. In long-term pretreatments most of the catechin may have been oxidized during regular cellular metabolism and due to factors such as transition metals present in the medium [36], which thereby may provide pre-conditioning. These results are in keeping with those of Chang et al. [7] where protection of chick embryo cardiomyocytes by $25 \mu \mathrm{M}$ catechin or procyanidin B2 was much more effective with long-term $(72 \mathrm{hr})$ pretreatment than with treatment during ischemia or reperfusion.

If not much antioxidant activity from catechin remained after 2-3-day pretreatment, why was protection observed? One possibility is that oxidized forms of catechins generated during long-term pretreatment activated specific signaling pathways involved in induction of endogenous antioxidants [40]. Consistent with this supposition, Du et al. [23] found that $24 \mathrm{~h}$ incubation of $\mathrm{H} 9 \mathrm{c} 2$ cells with $50-100 \mu \mathrm{M}$ (but not $25 \mu \mathrm{M})$ catechin or proanthocyanidin $B_{4}$ increased endogenous cellular antioxidants (glutathione) and antioxidant enzyme activities (superoxide dismutase, glutathione Stransferase, and catalase) and mitigated cell death caused by the xanthine oxidase system [23]. Consistent with such a preconditioning effect, we observed that feeding rats green tea catechins for 10 days prior to subjecting the isolated hearts to ischemia-reperfusion helped to protect the hearts from oxidative cell death along with maintaining relatively higher levels of phase 2 enzyme activities [24].

Using $t$-buOOH we compared the extent to which the different flavonoids protected against a pure oxidative stress. In the ischemia-reperfusion model, long-term treatment with the catechins protected, as did short-term treatment with a higher concentration of catechin. However, in $t$ buOOH-induced cell death the protection was only observed with short-term $(1 \mathrm{~h})$ pre-incubation with epigallocatechin gallate, while long-term (3 days) preincubation with epigallocatechin gallate or proanthocyanidins intensified the cytotoxicity of $t$-buOOH. This paradox may be related to the oxidation products of catechins, which include unstable dimer quinones [41], and would accumulate during long-term treatment. If such products become cytotoxic in reactions with $t$-buOOH it could account for the detrimental effects. 
With quercetin, while significant improvement in cell viability was observed in ischemia-reperfusion experiments only at $5 \mu \mathrm{M}$, it displayed the best protection against $t$-buOOH. This result suggests that quercetin may be the most effective as a direct-acting antioxidant, while the catechins may invoke other pathways.

Contrary to quercetin, ascorbate protected against ischemia-reperfusion but not against $t$-buOOH. One possible explanation for the lack of protection of ascorbate against $t$-buOOH is that ascorbate causes decomposition of organic hydroperoxides to cytotoxic species [42]. This diverse behaviour by flavonoids or ascorbate in different conditions of oxidative stress suggests that flavonoids and in general antioxidants may target an expanded number of signaling pathways within the cell. Different stimuli may engage different signaling pathways. As flavonoids differ in their chemical structure they probably vary in their interaction with these signaling pathways. If due to their structure some flavonoids work in broader signaling pathways, then they may have a capacity to show more extensive biological properties. In our study such a capacity was observed with epigallocatechin gallate which revealed to be effective against both ischemiareperfusion and $t$-buOOH (although in the latter only with short-term pretreatment). As catechin and proanthocyanidins were also helpful for alleviation of ischemia-reperfusion damage but failed to protect as well as epigallocatechin gallate, it is likely that the catechol ring can provide protection against ischemia-reperfusion, while the gallic acid moiety was important to combat against $t$-buOOH. More flavonoids exist in nature or can be synthesized which may have expansive capacities. Additionally, it is always possible to benefit from cotreatments. For instance, one might achieve better protection upon coadministration of quercetin with catechins in uncertain conditions of stress, especially in in vivo situations where cells are exposed to a variety of oxidants and stress stimuli.

In conclusion, the results support the possibility that catechins, which are richly present in teas and seeds, have the capacity to act as pre-conditioning agents to help protect heart cells from ischemia-reperfusion injury. Such preconditioning effects can occur at relatively low concentrations, while higher levels, which may be difficult to achieve through diet, are needed for direct antioxidant effects. In acute situations of oxidative stress quercetin and epigallocatechin gallate were the most potent antioxidants among the flavonoids tested. Directions for future research include investigations of the mechanisms involved, the roles of flavonoid metabolites, and potential synergisms with different flavonoids and with other antioxidants.

\section{Acknowledgments}

This work was supported by grants from the College of Pharmacy and Nutrition, the Canadian Institutes of Health Research (CIHR), and the Natural Sciences and Engineering Research Council (NSERC). M. Akhlaghi was supported by a $\mathrm{PhD}$ fellowship from the Iranian Ministry of Health and Medical Education.

\section{References}

[1] B. Nadal-Ginard, J. Kajstura, A. Leri, and P. Anversa, "Myocyte death, growth, and regeneration in cardiac hypertrophy and failure," Circulation Research, vol. 92, no. 2, pp. 139-150, 2003.

[2] J. Terao, Y. Kawai, and K. Murota, "Vegetable flavonoids and cardiovascular disease," Asia Pacific Journal of Clinical Nutrition, vol. 17, no. 1, supplement, pp. 291-293, 2008.

[3] A. W. Boots, G. R. M. M. Haenen, and A. Bast, "Health effects of quercetin: from antioxidant to nutraceutical," European Journal of Pharmacology, vol. 585, no. 2-3, pp. 325-337, 2008.

[4] S. Ramos, "Effects of dietary flavonoids on apoptotic pathways related to cancer chemoprevention," Journal of Nutritional Biochemistry, vol. 18, no. 7, pp. 427-442, 2007.

[5] S. Mandel, O. Weinreb, T. Amit, and M. B. H. Youdim, "Cell signaling pathways in the neuroprotective actions of the green tea polyphenol (-)-epigallocatechin-3-gallate: implications for neurodegenerative diseases," Journal of Neurochemistry, vol. 88, no. 6, pp. 1555-1569, 2004.

[6] M. Akhlaghi and B. Bandy, "Mechanisms of flavonoid protection against myocardial ischemia-reperfusion injury," Journal of Molecular and Cellular Cardiology, vol. 46, no. 3, pp. 309$317,2009$.

[7] W. T. Chang, Z. H. Shao, J. J. Yin et al., "Comparative effects of flavonoids on oxidant scavenging and ischemia-reperfusion injury in cardiomyocytes," European Journal of Pharmacology, vol. 566, no. 1-3, pp. 58-66, 2007.

[8] T. Okazaki, H. Otani, T. Shimazu et al., "Reversal of inducible nitric oxide synthase uncoupling unmasks tolerance to ischemia/reperfusion injury in the diabetic rat heart," Journal of Molecular and Cellular Cardiology, vol. 50, no. 3, pp. 534-544, 2011.

[9] R. J. Williams, J. P. E. Spencer, and C. Rice-Evans, "Flavonoids: antioxidants or signalling molecules?" Free Radical Biology and Medicine, vol. 36, no. 7, pp. 838-849, 2004.

[10] G. Poli, G. Leonarduzzi, F. Biasi, and E. Chiarpotto, "Oxidative stress and cell signalling," Current Medicinal Chemistry, vol. 11, no. 9, supplement, pp. 1163-1182, 2004.

[11] C. Manach, G. Williamson, C. Morand, A. Scalbert, and C. Rémésy, "Bioavailability and bioefficacy of polyphenols in humans. I. Review of 97 bioavailability studies," The American Journal of Clinical Nutrition, vol. 81, no. 1, supplement, pp. 230S-242S, 2005.

[12] S. Kim, M. J. Lee, J. Hong et al., "Plasma and tissue levels of tea catechins in rats and mice during chronic consumption of green tea polyphenols," Nutrition and Cancer, vol. 37, no. 1, pp. 41-48, 2000.

[13] V. C. J. De Boer, A. A. Dihal, H. Van Der Woude et al., "Tissue distribution of quercetin in rats and pigs," Journal of Nutrition, vol. 135, no. 7, pp. 1718-1725, 2005.

[14] M. Levine, S. J. Padayatty, and M. G. Espey, "Vitamin C: a concentration-function approach yields pharmacology and therapeutic discoveries," Advances in Nutrition, vol. 2, no. 2, pp. 78-88, 2011.

[15] T. G. Maddaford, C. Hurtado, S. Sobrattee, M. P. Czubryt, and G. N. Pierce, "A model of low-flow ischemia and reperfusion in single, beating adult cardiomyocytes," American Journal of Physiology, vol. 277, no. 2, part 2, pp. H788-H798, 1999.

[16] F. Denizot and R. Lang, "Rapid colorimetric assay for cell growth and survival - Modifications to the tetrazolium dye procedure giving improved sensitivity and reliability," Journal of Immunological Methods, vol. 89, no. 2, pp. 271-277, 1986.

[17] S. C. Vashishtha, A. J. Nazarali, and J. R. Dimmock, "Application of fluorescence microscopy to measure apoptosis in Jurkat 
$\mathrm{T}$ cells after treatment with a new investigational anticancer agent (N.C.1213)," Cellular and Molecular Neurobiology, vol. 18, no. 4, pp. 437-446, 1998.

[18] I. Maestre, J. Jordán, S. Calvo et al., "Mitochondrial dysfunction is involved in apoptosis induced by serum withdrawal and fatty acids in the $\beta$-cell line INS-1," Endocrinology, vol. 144, no. 1, pp. 335-345, 2003.

[19] A. R. King, S. E. Francis, C. J. Bridgeman, H. Bird, M. K. B. Whyte, and D. C. Crossman, "A role for caspase-1 in serum withdrawal-induced apoptosis of endothelial cells," Laboratory Investigation, vol. 83, no. 10, pp. 1497-1508, 2003.

[20] V. Voccoli, F. Mazzoni, M. Garcia-Gil, and L. Colombaioni, "Serum-withdrawal-dependent apoptosis of hippocampal neuroblasts involves $\mathrm{Ca}^{2+}$ release by endoplasmic reticulum and caspase-12 activation," Brain Research, vol. 1147, no. 1, pp. 1-11, 2007.

[21] E. Murphy and C. Steenbergen, "Mechanisms underlying acute protection from cardiac ischemia-reperfusion injury," Physiological Reviews, vol. 88, no. 2, pp. 581-609, 2008.

[22] J. B. Ray, S. Arab, Y. Deng et al., "Oxygen regulation of arterial smooth muscle cell proliferation and survival," American Journal of Physiology, vol. 294, no. 2, pp. H839-H852, 2008.

[23] Y. Du, H. Guo, and H. Lou, "Grape seed polyphenols protect cardiac cells from apoptosis via induction of endogenous antioxidant enzymes," Journal of Agricultural and Food Chemistry, vol. 55, no. 5, pp. 1695-1701, 2007.

[24] M. Akhlaghi and B. Bandy, "Dietary green tea extract increases phase 2 enzyme activities in protecting against myocardial ischemia-reperfusion," Nutrition Research, vol. 30, no. 1, pp. 32-39, 2010.

[25] M. A. Potenza, F. L. Marasciulo, M. Tarquinio et al., "EGCG, a green tea polyphenol, improves endothelial function and insulin sensitivity, reduces blood pressure, and protects against myocardial I/R injury in SHR," American Journal of Physiology, vol. 292, no. 5, pp. E1378-E1387, 2007.

[26] K. G. Yamazaki, D. Romero-Perez, M. Barraza-Hidalgo et al., "Short- and long-term effects of (-)-epicatechin on myocardial ischemia-reperfusion injury," American Journal of Physiology, vol. 295, no. 2, pp. H761-H767, 2008.

[27] D. Modun, I. Musić, V. Katalinić, I. Salamunić, and M. Boban, "Comparison of protective effects of catechin applied in vitro and in vivo on ischemia-reperfusion injury in the isolated rat hearts," Croatian Medical Journal, vol. 44, no. 6, pp. 690-696, 2003.

[28] M. Hirai, Y. Hotta, N. Ishikawa et al., "Protective effects of EGCg or GCg, a green tea catechin epimer, against postischemic myocardial dysfunction in guinea-pig hearts," Life Sciences, vol. 80, no. 11, pp. 1020-1032, 2007.

[29] R. Aneja, P. W. Hake, T. J. Burroughs, A. G. Denenberg, H. R. Wong, and B. Zingarelli, "Epigallocatechin, a green tea polyphenol, attenuates myocardial ischemia reperfusion injury in rats," Molecular Medicine, vol. 10, no. 1-6, pp. 55$62,2004$.

[30] S. Mandel, L. Reznichenko, T. Amit, and M. B. H. Youdim, "Green tea polyphenol (-)-epigallocatechin-3-gallate protects rat PC12 cells from apoptosis induced by serum withdrawal," Neurotoxicity Research, vol. 5, no. 6, pp. 419-424, 2003.

[31] M. Ikizler, N. Erkasap, S. Dernek, T. Kural, and Z. Kaygisiz, "Dietary polyphenol quercetin protects rat hearts during reperfusion: enhanced antioxidant capacity with chronic treatment," Anadolu Kardiyoloji Dergisi, vol. 7, no. 4, pp. 404 410, 2007.
[32] S. Yamashiro, K. Noguchi, T. Matsuzaki et al., "Cardioprotective effects of extracts from Psidium guajava L. and Limonium wrightii, Okinawan Medicinal Plants, against ischemiareperfusion injury in perfused rat hearts," Pharmacology, vol. 67, no. 3, pp. 128-135, 2003.

[33] A. M. Amorini, G. Lazzarino, F. Galvano, G. Fazzina, B. Tavazzi, and G. Galvano, "Cyanidin-3-O- $\beta$-glucopyranoside protects myocardium and erythrocytes from oxygen radicalmediated damages," Free Radical Research, vol. 37, no. 4, pp. 453-460, 2003.

[34] H. J. Kim, I. Tsoy, J. M. Park, J. I. Chung, S. C. Shin, and K. C. Chang, "Anthocyanins from soybean seed coat inhibit the expression of TNF- $\alpha$-induced genes associated with ischemia/ reperfusion in endothelial cell by NF- $\kappa \mathrm{B}$-dependent pathway and reduce rat myocardial damages incurred by ischemia and reperfusion in vivo," FEBS Letters, vol. 580, no. 5, pp. 13911397, 2006.

[35] M. C. Toufektsian, M. de Lorgeril, N. Nagy et al., "Chronic dietary intake of plant-derived anthocyanins protects the rat heart against ischemia-reperfusion injury," Journal of Nutrition, vol. 138, no. 4, pp. 747-752, 2008.

[36] L. M. Wee, L. H. Long, M. Whiteman, and B. Halliwell, "Factors affecting the ascorbate- and phenolic-dependent generation of hydrogen peroxide in Dulbecco's Modified Eagles Medium," Free Radical Research, vol. 37, no. 10, pp. 11231130, 2003.

[37] A. Ichiki, T. Miyazaki, M. Nodera, H. Suzuki, and H. Yanagisawa, "Ascorbate inhibits apoptosis of kupffer cells during warm ischemia/reperfusion injury," Hepato-Gastroenterology, vol. 55, no. 82-83, pp. 338-344, 2008.

[38] A. Korkmaz and D. Kolankaya, "The protective effects of ascorbic acid against renal ischemia-reperfusion injury in male rats," Renal Failure, vol. 31, no. 1, pp. 36-43, 2009.

[39] O. H. Higa, E. R. Parra, A. M. Ab'Saber, C. Farhat, R. Higa, and V. L. Capelozzi, "Protective effects of ascorbic acid pretreatment in a rat model of intestinal ischemia-reperfusion injury: a histomorphometric study," Clinics, vol. 62, no. 3, pp. 315320, 2007.

[40] C. Chen, R. Yu, E. D. Owuor, and A. N. Tony Kong, "Activation of antioxidant-response element (ARE), mitogen-activated protein kinases (MAPKs) and caspases by major green tea polyphenol components during cell survival and death," Archives of Pharmacal Research, vol. 23, no. 6, pp. 605-612, 2000.

[41] T. Tanaka and I. Kouno, "Oxidation of tea catechins: chemical structures and reaction mechanism," Food Science and Technology Research, vol. 9, no. 2, pp. 128-133, 2003.

[42] Seon Hwa Lee, T. Oe, and I. A. Blair, "Vitamin C-induced decomposition of lipid hydroperoxides to endogenous genotoxins," Science, vol. 292, no. 5524, pp. 2083-2086, 2001. 


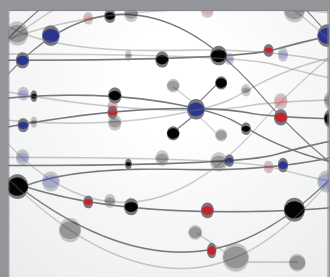

The Scientific World Journal
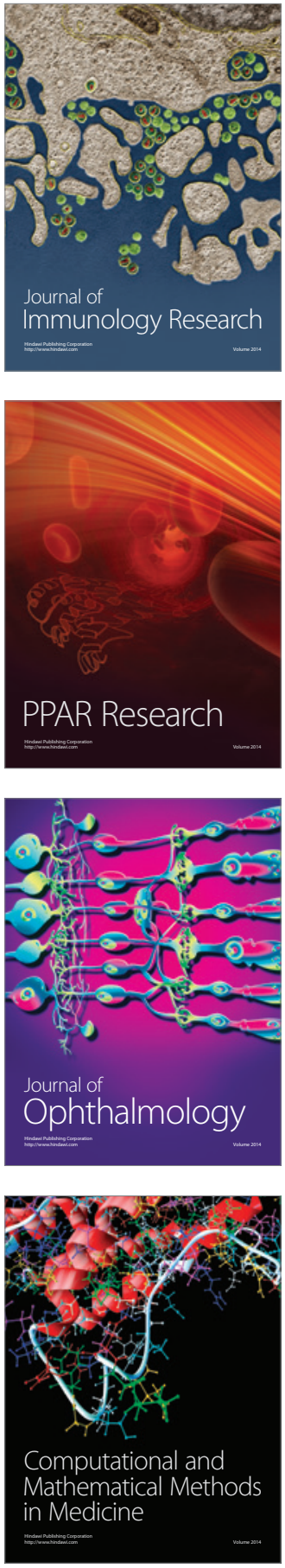

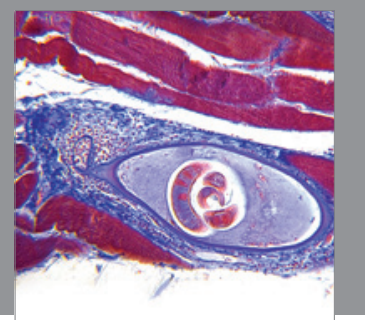

Gastroenterology

Research and Practice
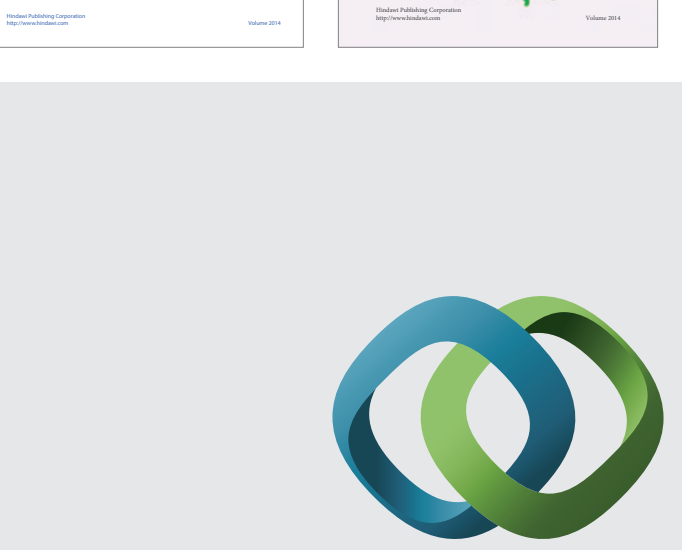

\section{Hindawi}

Submit your manuscripts at

http://www.hindawi.com
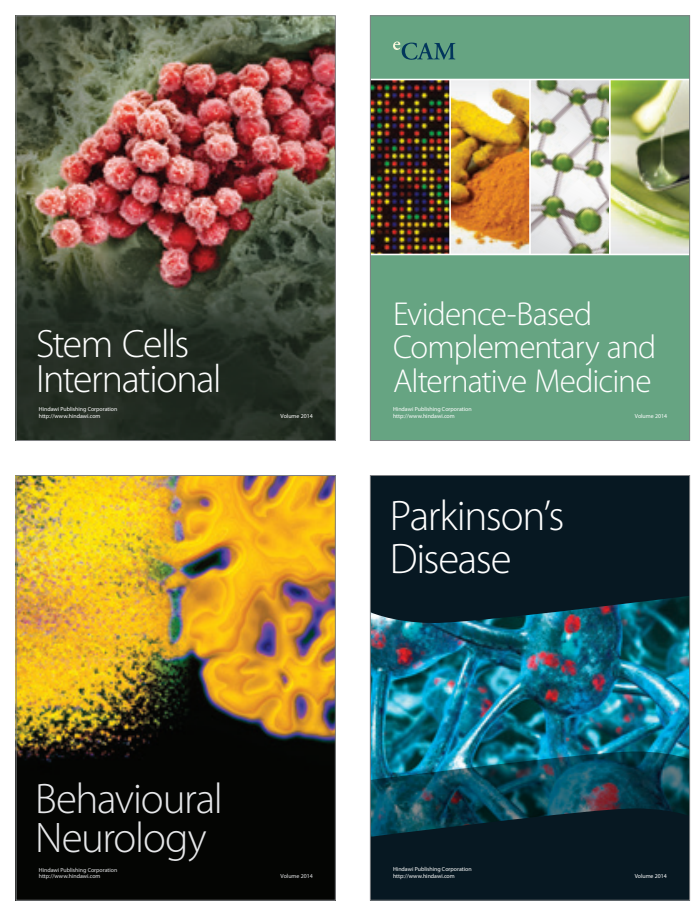

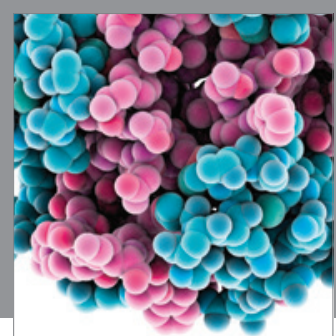

Journal of
Diabetes Research

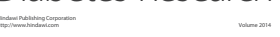

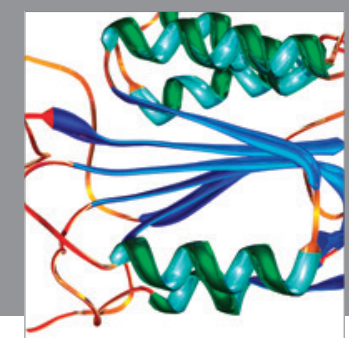

Disease Markers
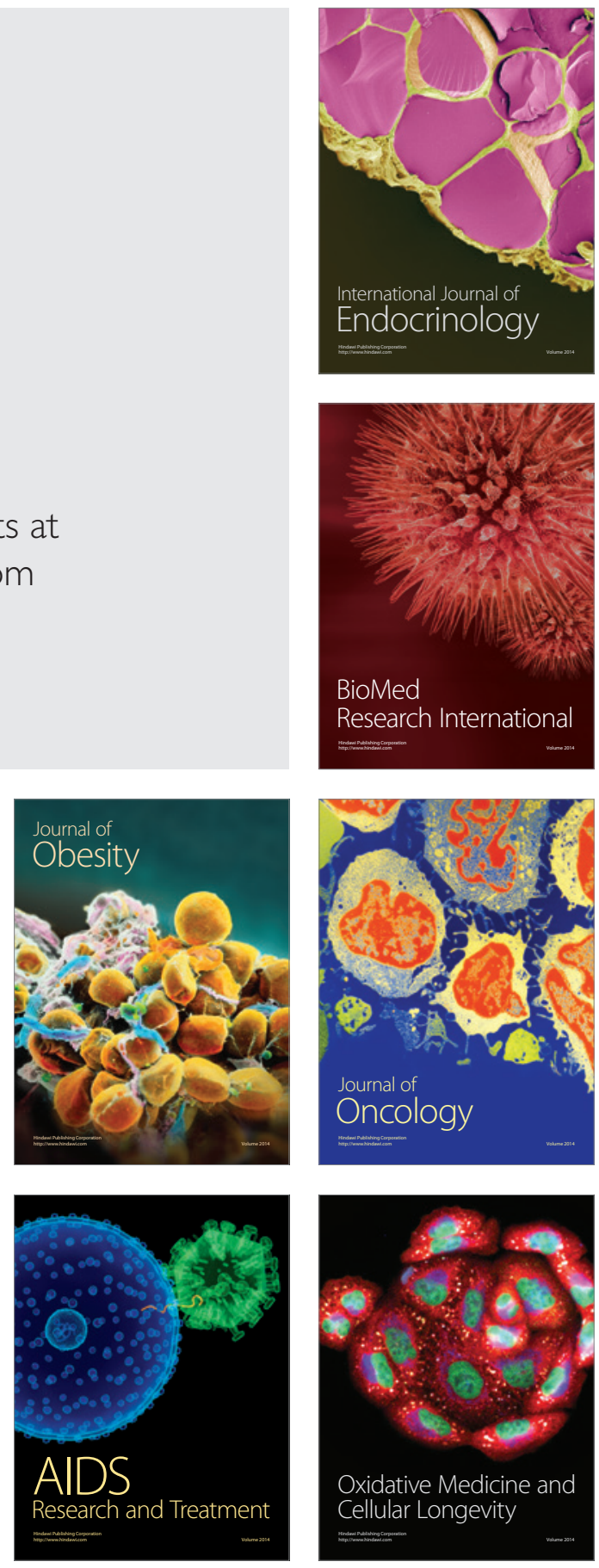